\title{
PERAN KOMITE SEKOLAH \\ DALAM PENINGKATAN MUTU PEMBELAJARAN DI SEKOLAH DASAR
}

\author{
Ali Mustadi, Enny Zubaidah, dan Sumardi \\ Fakultas Ilmu Pendidikan Universitas Negeri Yogyakarta \\ email: ali_mustadi@uny.ac.id
}

\begin{abstract}
Abstrak: Penelitian ini bertujuan untuk mengevaluasi keterlaksanaan peran komite sekolah ditinjau dari peningkatan mutu pembelajaran di SD se-Kabupaten Bantul. Penelitian ini adalah penelitian evaluatif dengan pendekatan evaluasi model Stake. Subjek penelitian adalah komite sekolah, kepala sekolah, dan guru SD di Kabupaten Bantul. Pengumpulan data menggunakan teknik angket, observasi, dan dokumentasi. Data dianalisis lewat penghitungan persentase dan disimpulkan berdasarkan kriteria yang telah ditetapkan. Hasil penelitian adalah sebagai berikut. (1) Tahap antecedent (input dan perencanaan) pemahaman responden terhadap rancangan program implementasi peran Komite Sekolah belum sepenuhnya sesuai dengan standar dan berkategori cukup dengan persentase $36 \%$. (2) Tahap transaction terhadap implementasi program komite sekolah telah terlaksana dengan kategori baik (58\%). (3) Tahap outcomes, yaitu evaluasi terhadap implementasi peran Komite Sekolah terhadap tahap antecedent dan transaction masuk kategori cukup (47\%). Implementasi peran program komite sekolah di SD Kabupaten Bantul belum memenuhi standar $100 \%$. Oleh karena itu, hasil temuan dari penelitian ini diharapkan bisa dijadikan bahan untuk meningkatkan kinerja dari semua pihak.
\end{abstract}

Kata kunci: komite sekolah, mutu pembelajaran, Sekolah Dasar

\section{THE ROLE OF SCHOOL COMMITTEE IN IMPROVING PRIMARY EDUCATION QUALITY}

\begin{abstract}
The aim of this study is to evaluate the implementation of the school committee role seen from the improvement of the learning quality in primary schools throughout Bantul district. The research subjects were school committees, headmasters, and primary school teachers in Bantul district. Data were collected through various techniques, i.e.questionnaires, observation, and documentation. The results show that: (1) the antecedent phase (input and planning) of respondents' understanding concerning the design program of the School Committee role is not fully in accordance with the standard and thus can be categorized medium by the percentage of $36 \%$; (2) the transaction phase related to the implementation of the school committee program can be categorizedgood(58\%); (3) the outcomes phase namely the evaluation of the implementation of School Committee role to the antecedent phase and the transaction phase can be categorized adequate $(47 \%)$. The implementation of the role of school committee program in primary schools in Bantul district does not reach $100 \%$ of the standard. These findings are expected to motivate everyone to improve their performance.
\end{abstract}

Keywords: school committee, learning quality,

\section{PENDAHULUAN}

Pendidikan memegang peranan penting dalam pembangungan sumber daya manusia Indonesia. Peran penting pendidikan dalam pembangunan sumber daya manusia diakomodasi pemerintah melalui institusi pendidikan, baik formal maupun informal. Pada institusi pendidikan formal, proses pendidikan dilakukan di sekolah. Pendidikan di sekolah dilaksanakan melalui pembelajaran yang dilakukan oleh guru kepada siswa.
Menurut UU Sistem Pendidikan Nasional No. 20 Tahun 2003 Pasal 1 ayat 20 disebutkan bahwa pembelajaran adalah proses interaksi peserta didik dengan pendidik dan sumber belajar pada suatu lingkungan belajar.

Pembelajaran di sekolah oleh guru harus dilaksanakan dengan baik dan bermutu. Pembelajaran yang bermutu berkorelasi dengan persiapan yang baik. Persiapan tersebut meliputi perencanaan dan pemilihan strategi pembelajaran, 
sebagaimana dikatakan oleh Jones (2015:99) bahwa keberhasilan dalam pembelajaran sangat tergantung pada efektivitas perencanaan serta seberapa baik menempatkan rencana tersebut ke dalam tindakan. Perencanaan dianggap sebagai kunci pembelajaran yang dapat membuat siswa belajar secara efektif, menarik, bervariasi, dan progresif. Melalui perencanaan yang baik, guru dapat mengidentifikasi bagaimana siswa belajar dan membuat kemajuan. (The Qualifications and Curriculum Authority, 2015:2)

Strategi pembelajaran merupakan bagian dari proses perencanaan pembelajaran. Kavaliauskienë (2011) menjelaskannya sebagai suatu sistem pengajaran yang mengandung prosedur sistematis sehingga guru dapat mengorganisir materi dan kegiatan untuk mencapai tujuan yang diinginkan dalam pembelajaran. Namun, dalam kapasitasnya, keberhasilan suatu pembelajaran serta berkembangnya mutu pendidikan, tidak hanya ditentukan oleh perencanaan dan strategi yang telah dibangun oleh guru dan sekolah. Terdapat pilar penting yang mempengaruhinya, yaitu keselarasan dukungan dari para orang terdekat siswa dan masyarakat. Kaitannya dengan masyarakat, Guskey (2001) menyampaikan bahwa sudah menjadi kewajiban masyarakat untuk turut berpartisipasi dan memberikan perhatian kemajuan proses pendidikan.

Kesuksesan seorang siswa tidak hanya sebuah hasil yang disebabkan oleh faktor sekolah, namun secara bersama-sama antara sekolah, keluarga, dan masyarakat. Berg (2006:3) menjelaskan bahwa kemitraan antara sekolah dengan keluarga serta masyarakat dapat menghasilkan solusi kreatif untuk mengetahui kebutuhan dari siswa. sehingga kehadiran mereka dapat membawa misi untuk membangun insan dan ekosistem pendidikan yang berbudaya serta berkarakter berlandaskan gotong royong. Dalam hal ini Bryan \& Henry (2012) mempresentasikan bahwa ketika pemangku kepentingan (sekolah, keluarga, dan masyarakat) saling berkontributif membangun kemitraan, maka akan memunculkan efek positif terhadap prestasi belajar dan kedisiplinan dalam diri siswa. Oleh karena itu, diharapkan kemitraan pendidikan tersebut dapat berjalan dengan baik dan bermakna.

Peran masyarakat dan orangtua dalam peningkatan mutu pendidikan di sekolah diakomodasi melalui sebuah badan bernama Komite Sekolah. UU Sistem Pendidikan Nasional No. 20 tahun
2003 Pasal 56 ayat (3) menyatakan bahwa komite sekolah/madrasah, sebagai lembaga mandiri, dibentuk dan berperan dalam peningkatan mutu pelayanan dengan memberikan pertimbangan, arahan dan dukungan tenaga, sarana dan prasarana, serta pengawasan pendidikan pada tingkat satuan pendidikan.

Komite Sekolah merupakan mitra sekolah dalam meningkatkan kualitas pelayanan pendidikan. Sebagai mitra sekolah, komite sekolah harus menjadi badan yang otonom agar memiliki posisi yang sejajar dengan sekolah. Di dalam UU No. 25 tahun 2000 tentang program pembangunan nasional (Propenas) 2000-2004 dan Keputusan Menteri Pendidikan Nasional No. 044/U/2002 tentang Dewan Pendidikan dan Komite Sekolah disebutkan bahwa Dewan Pendidikan dan Komite Sekolah merupakan badan yang bersifat mandiri dan otonom serta menganut asas kebersamaan dan tidak mempunyai hubungan hierarkis dengan Dinas Pendidikan maupun lembaga-lembaga lainnya di suatu kabupaten/kota. Pantjastuti (2008:8081) mengungkapkan bahwa komite sekolah dan sekolah memiliki kemandirian masing-masing tetapi tetap sebagai mitra yang harus saling bekerja sama sejalan dengan konsep manajemen berbasis sekolah.

Kemendikbud (2016) menyebutkan bahwa program kemitraan melalui komite sekolah ini bertujuan untuk: (1) menguatkan jalinan kemitraan antara sekolah, keluarga, dan masyarakat dalam mendukung lingkungan belajar yang dapat mengembangkan potensi anak secara utuh; (2) meningkatkan keterlibatan orang tua/wali dalam mendukung keberhasilan pendidikan anak di rumah dan di sekolah; dan (3) meningkatkan peran serta masyarakat dalam mendukung program pendidikan di sekolah dan di masyarakat.

Terdapat lima elemen gambaran kerja sama orang tua dan sekolah di antaranya: (1) komunikasi yang efektif; (2) membangun komunitas belajar; (3) menjalin hubungan dengan sekolah dan masyarakat luas; (4) mengambil keputusan bersama; (5) serta turut berpartisipasi mendukung dan membantu berjalannya program. Department of Education, Training and Employment (2014)

Hal ini sebagaimana termaktub dalam UU Sistem Pendidikan Nasional No. 20 Tahun 2003 Pasal 56 ayat (3) yang menyatakan bahwa Komite Sekolah atau madrasah, sebagai lembaga mandiri, dibentuk dan berperan dalam peningkatan mutu pelayanan dengan memberikan pertimbangan, 
arahan dan dukungan tenaga, sara dan prasarana, serta pengawasan pendidikan pada tingkat satuan pendidikan.

Keberadaan Komite Sekolah diharapkan tidak menjadi sebuah formalitas semata. Sebagai sebuah badan yang mandiri, Komite Sekolah memiliki komitmen dan loyalitas terhadap peningkatan kualitas pendidikan sebagimana pendapat dari Sagala (2009:251) yang menyatakan bahwa Dewan Pendidikan dan Komite Sekolah merupakan organisasi masyarakat pendidikan yang mempunyai komitmen dan loyalitas serta peduli terhadap peningkatan kualitas di daerahnya.

Sebagai badan kemitraan sekolah yang mewadahi konektivitas antara sekolah, keluarga, dan masyarakat, kedudukan komite sekolah memiliki fungsi yang penting seperti yang disampaikan oleh Rehberg (2008) yaitu: (1) memberikan kebijakan; (2) memberikan penilaian; (3) menyediakan sumber dana keuangan; (4) menjembatani hubungan dengan masyarakat luas: serta (5) melakukan perencanaan dan evaluasi pendidikan.

Mengingat peran penting komite sekolah terhadap upaya peningkatan mutu pembelajaran, sekolah perlu menjalin hubungan baik dengan orang tua dan masyarakat. Hal ini sangat diperlukan oleh sekolah untuk membantu keberhasilan program-program sekolah. Mulyasa (2009: 50) menyatakan bahwa tujuan membina hubungan antara sekolah dan masyarakat antara lain (1) memajukan mutu pembelajaran, dan pertumbuhan anak; (2) memperkokoh tujuan serta meningkatkan mutu hidup dan penghidupan masyarakat; dan (3) menggairahkan masyarakat untuk menjalin hubungan baik dengan masyarakat.

Peran masyarakat melalui komite sekolah/ madrasah selanjutnya diatur dalam pasal 56 ayat (3) yaitu bahwa komite sekolah/madrasah, sebagai lembaga mandiri, dibentuk dan berperan dalam peningkatan mutu pelayanan dengan memberikan pertimbangan, arahan dan dukungan tenaga, sarana dan prasarana, serta pengawasan pendidikan pada tingkat satuan pendidikan.

Fungsi dan tugas Dewan Pendidikan dan Komite Sekolah diatur dalam Peraturan Pemerintah Nomor 17 Tahun 2010 tentang Pengelolaan dan Penyelenggaraan Pendidikan secara jelas mengatur fungsi dan tugas Dewan Pendidikan dan Komite Sekolah. Fungsi dan tugas Komite Sekolah dimuat pada Pasal 196 ayat (1) yang menyebutkan bahwa komite sekolah/madrasah memiliki fungsi dalam peningkatan mutu pendidikan meliputi memberikan pertimbangan, arahan dan dukungan tenaga, sarana dan prasarana, serta pengawasan. Komite sekolah/madrasah menjalankan fungsinya pada tingkat satuan pendidikan tertentu..

Cara komite sekolah dalam menjalankan fungsinya diatur dalam pasal 196 ayat (2) yang mengandung penjelasan bahwa komite sekolah/ madrasah menjalankan fungsinya secara mandiri dan profesional. Sebagai badan yang mandiri, komite sekolah/ madrasah tidak mengesampingkan masukan, saran, kritik, maupun aspirasi masyarakat. Pada pasal 196 ayat 3 disebutkan bahwa dalam menjalankan fungsinya, komite sekolah/madrasah mendengarkan segala masukan masyarakat. Komite sekolah/madrasah juga menindaklanjuti segala aspirasi masyarakat terkait peningkatan mutu pendidikan.

Hal tersebut sejalan dengan Sagala (2009: 257) bahwa komite sekolah memiliki fungsi yaitu sebagai pemberi pertimbangan, pendukung, pengontrol, dan mediator. Pemberian pertimbangan mengenai (1) program dan kegiatan yang disusun dalam rencana pembangunan pendidikan tingkat kabupaten/kota dan RKS serta RKT tingkat satuan pendidikan; (2) pertimbangan kepada guru dalam pelaksanaan tugas supaya tidak sewenang-wenang dalam menangani siswa (misalnya dalam hal memberi hukuman bagi siswa); (3) pertimbangan dalam hal peningkatan disiplin guru dan memberi solusi bagi kesulitan-kesulitan yang dihadapi guru; (4) pertimbangan dalam mengembangkan bakat dan minat siswa (misalnya dalam keikutsertaan siswa dalam lomba-lomba).

Fungsi kedua sebagai pendukung antara lain (1) mendata jumlah guru yang memerlukan pendidikan dan latihan, mendata tingkat pendidikan guru yang memerlukan peningkatan kualifikasi pendidikan; (2) memberikan pelatihan mengenai mata pelajaran dan layanan belajar bagi guru yang membutuhkan; (3) mendata jumlah siswa dan indeks prestasinya, guru dan Komite Sekolah; (4) mendukung program pengayaan bagi siswa yang lebih pintar, dan remedial bagi siswa yang belum mencapai hasil yang dipersyaratkan; (5) menyediakan hadiah dan trophy bagi siswa yang menjuarai perlombaan; (6) mengadakan kegiatan pesantren kilat; (7) mendukung pemanfaatan sarana-prasarana untuk mendukung pembelajaran; (8) membuat media pembelajaran sesuai kebutuhan belajar siswa; (9) membuat kebun percontohan sekolah; (10) memaksimalkan alokasi anggaran 
operasional sekolah yang bersumber dari APBD, dan bantuan lain.

Fungsi Dewan Pendidikan dan Komite Sekolah sebagai pengontrol antara lain (1) menanyakan proses belajar mengajar apakah sudah mengarah pada standar yang dipersyaratkan; (2) menanyakan kondisi kesehatan, gizi, dan bakat peserta didik; (3) memantau pelaksanaan Rencana Kegiatan Sekolah (RKS) dan Rencana Kegiatan Tahunan (RKT); (4) ikut serta dalam penyusunan RKS dan RKT; (5) ikut memantau penggunaan dana BOS; (6) ikut dalam rapat pembagian rapor; (7) mengontrol kesejahteraan guru dan tenaga kependidikan lainnya; (8) mengontrol pelaksanaan proses belajar mengajar guru.

Berdasarkan latar belakang di atas, penelitian ini bertujuan untuk mengevaluasi peran Komite Sekolah dalam peningkatan mutu pembelajaran di SD di Kabupaten Bantul.

\section{METODE}

Penelitian ini menggunakan jenis penelitian evaluasi (evaluative research) yang bertujuan untuk mengevaluasi peran Komita Sekolah di Sekolah Dasar (SD) di Kabupaten Bantul dengan menggunakan model evaluasi Stake (Stake's Countenance Model) yang mengukur keterlaksanaan proses peran Komite Sekolah yang terjadi di lapangan dengan standar peran Komite Sekolah yang seharusnya sebagai kriteria untuk menentukan keberhasilan. Desain evaluasi model Stake's Countenance Model menekankan adanya pelaksanaan dua hal pokok yakni deskripsi (description) dan pertimbangan keputusan (judgements). Dua hal pokok ini dibedakan dalam tiga tahap evaluasi program yaitu: (1) input dan perencanaan (antecedent), (2) proses (transaction), (3) hasil (outcomes). Model evaluasi Stake merupakan metode yang sistimatis untuk mengevaluasi keterlaksanaan proses peran Komite Sekolah secara menyeluruh yang meliputi rencana, pelaksanaan, dan pelaksanan penilaian hasil.

Penelitian ini dilaksanakan di Sekolah Dasar di wilayah Kabupaten Bantul. Populasi penelitian adalah seluruh SDN di Kabupaten Bantul. Teknik sampling yang digunakan adalah Probality Sampling Technique (Sugiyono, 2012). Seluruh kecamatan menjadi sampel daerah. Penentuan subjek/orang sebagai sampel di tiap daerah dilakukan dengan acak atau random sehingga semua anggota populasi memiliki kesempatan yang sama untuk dijadikan anggota sampel. Jumlah populasi
SD di Kabupaten Bantul terpilih sebanyak 148 SD sehingga jumlah sampel yang selayaknya 95 SD. Langkah selanjutnya adalah menentukan ukuran sampel yang proporsional sesuai dengan jumlah populasi di setiap daerah kelurahan.

Data dikumpulkan lewat angket, observasi, dan dokumentasi. Analisis data dilakukan dengan menggunakan teknik statistik deskriptif yang berupa penghitungan analisis presentase dan kemudian dideskripsikan dan disimpulkan berdasarkan kriteria yang telah ditentukan.

\section{HASIL}

Evaluasi keterlaksanaan peran komite sekolah ditinjau dari peningkatan mutu pembelajaran di SD se-Kabupaten Bantul menekankan dua hal utama yaitu melakukan penggambaran dan pertimbangan. Data yang diperoleh dalam penelitian ini dibedakan menjadi tiga bagian yaitu input dan perencanaan, proses/pelaksanaan, dan hasil/evaluasi. Pada masing-masing tahapan akan dilihat (secara horisontal) kesesuaiannya antara perencanaan dan data hasil implementasi yang diperoleh dari observasi lapangan. Analisis lanjutan untuk mencari kesesuaian antara pelaksanaan program komite sekolah yang diharapkan sesuai standar dengan yang diamati pada masing-masing tahapan. Hasil analisis data evaluasi ditampilkan dalam Tabel 1.

\section{Tahap Perencanaan}

Hasil evaluasi terhadap tahap input dan perencanaan (Antecedent Phase) yang dilakukan terhadap pelaksanaan program Komite Sekolah menunjukkan pemahaman terhadap rancangan program implementasi peran Komite Sekolah berkategori cukup dengan persentase $36 \%$. Angka tersebut mempresentasikan bahwa pemahaman terhadap rancangan implementasi peran komite sekolah belum sepenuhnya sesuai dengan standar. Rancangan program yang dimaksud dalam hal ini yaitu konsep, fungsi dan tujuan, serta manfaat komite sekolah.

\section{Tahap Proses}

Pada kolom proses (transaction) menunjukkan bahwa komite sekolah telah melaksanakan peran program komite sekolah sebagai pemberi pertimbangan, pendukung, pengontrol dan mediator dalam upaya peningkatan mutu pembelajaran dengan kategori baik yaitu sebesar 58\% (rentang 51-75\%). 
Tabel 1. Data hasil evaluasi implementasi program komite sekolah

\begin{tabular}{|c|c|c|c|c|c|}
\hline \multirow{2}{*}{ Tahap } & \multirow{2}{*}{ ASPEK } & \multicolumn{2}{|c|}{ Description matrix } & \multicolumn{2}{|c|}{ Judgment matrix } \\
\hline & & Intents & Obervations & Standards & Judgments \\
\hline $\begin{array}{l}\text { Input dan } \\
\text { Perencanaan } \\
\text { (Antecedent) }\end{array}$ & $\begin{array}{l}\text { Pemahaman } \\
\text { terhadap } \\
\text { rancangan } \\
\text { program } \\
\text { implementasi } \\
\text { peran Komite } \\
\text { Sekolah }\end{array}$ & $\begin{array}{l}\text { Konsep Komite } \\
\text { Sekolah, fungsi dan } \\
\text { tujuan, dan manfaat }\end{array}$ & $36 \%$ & $100 \%$ & $\begin{array}{l}\text { Belum sesuai, } \\
\text { diberikan } \\
\text { pertimbangan }\end{array}$ \\
\hline \multirow{4}{*}{$\begin{array}{l}\text { Proses } \\
\text { (Transaction) }\end{array}$} & \multirow{4}{*}{$\begin{array}{l}\text { Implementasi } \\
\text { program } \\
\text { komite } \\
\text { sekolah }\end{array}$} & $\begin{array}{l}\text { Peran komite sekolah } \\
\text { sebagai pemberi } \\
\text { pertimbangan }\end{array}$ & $54 \%$ & $100 \%$ & \multirow{4}{*}{$\begin{array}{l}\text { Belum sesuai, } \\
\text { diberikan } \\
\text { pertimbangan } \\
\text { Belum sesuai, } \\
\text { diberikan } \\
\text { pertimbangan } \\
\text { Belum sesuai, } \\
\text { diberikan } \\
\text { pertimbangan } \\
\text { Belum sesuai, } \\
\text { diberikan } \\
\text { pertimbangan }\end{array}$} \\
\hline & & $\begin{array}{l}\text { Peran komite sekolah } \\
\text { sebagai pendukung }\end{array}$ & $57 \%$ & $100 \%$ & \\
\hline & & $\begin{array}{l}\text { peran komite sekolah } \\
\text { sebagai pengontrol }\end{array}$ & $51 \%$ & $100 \%$ & \\
\hline & & $\begin{array}{l}\text { Peran komite sekolah } \\
\text { sebagai mediator }\end{array}$ & $52 \%$ & $100 \%$ & \\
\hline $\begin{array}{l}\text { Hasil } \\
\text { (outcomes) }\end{array}$ & $\begin{array}{l}\text { Evaluasi } \\
\text { implementasi } \\
\text { peran Komite } \\
\text { Sekolah }\end{array}$ & $\begin{array}{l}\text { Evaluasi } \\
\text { keterlaksanaan }\end{array}$ & $47 \%$ & $100 \%$ & $\begin{array}{l}\text { Belum sesuai, } \\
\text { diberikan } \\
\text { pertimbangan }\end{array}$ \\
\hline
\end{tabular}

Tabel 2. Bagan Pengolahan Data Deskripsi Model Stake

\begin{tabular}{|c|c|c|c|}
\hline Keadaan yang Diharapkan (intented) & & & $\begin{array}{c}\text { Keadaan yang } \\
\text { Sebenarnya }\end{array}$ \\
\hline $\begin{array}{l}\text { Antecedent } \\
\text { Pemahaman terhadap rancangan program implementasi } \\
\text { peran Komite Sekolah }\end{array}$ & $100 \%$ & $\stackrel{\text { Kesesuaian }}{\longleftrightarrow}$ & $36 \%$ \\
\hline Kesenjangan & & & Kesenjangan \\
\hline $\begin{array}{l}\text { Transaction } \\
\text { Implementasi program komite sekolah }\end{array}$ & $100 \%$ & $\stackrel{\text { Kesesuaian }}{\longleftrightarrow}$ & $58 \%$ \\
\hline Kesenjangan & & & Kesenjangan \\
\hline $\begin{array}{l}\text { Outcomes } \\
\text { Evaluasi implementasi peran Komite Sekolah }\end{array}$ & $100 \%$ & $\underset{\text { Kesesuaian }}{\longleftrightarrow}$ & $47 \%$ \\
\hline
\end{tabular}

Masing-masing hasil pada tahap transaction juga menjelaskan bahwa peranan komite sebagai pemberi pertimbangan telah melaksanakan sebesar 54\%. Hasil peran komite sekolah sebagai pemberi pertimbangan belum mencapai standar yang telah ditentukan sehingga masih perlu diberikan pertimbangan perbaikan. Peran komite sekolah sebagai pendukung terhadap sekolah telah terlaksana dengan kategori baik dengan persentase $57 \%$. Mayoritas responden menjawab dengan skala tinggi sehingga dapat diketahui bahwa pelaksanaan peran program komite sekolah telah terlaksana dengan baik.
Peran komite sekolah sebagai pengontrol telah terlaksana dengan kategori baik yaitu sebesar $51 \%$. Peran sebagai pengontrol yang telah dilakukan dengan skala jawaban tinggi dari rensponden hampir pada semua indikator. Keadaan tersebut mempresentasikan suatu potensi yang dimiliki oleh komite sekolah untuk menjalankan perannya menjadi pengontrol, sehingga perlu diberikan pertimbangan-pertimbangan yang membangun agar potensi tersebut dapat terwujud dengan optimal. Peran komite sekolah sebagai mediator telah terlaksana dengan baik pula yaitu sebesar 
$52 \%$. Modus jawaban dengan skala "tinggi" juga diperoleh dari indikator-indikator penduungnya.

\section{Tahap Hasil}

Evaluasi keterlaksanaan komite sekolah telah menunjukan kategori baik, yaitu dengan presentase $47 \%$. Namun pencapaian tersebut belum menunjukan keterlaksanaan yang optimal, sehingga perlu diberikan pertimbangan saran kearah perbaikan demi menghasilkan outcomes yang lebih baik. Data hasil evaluasi implementasi program komite sekolah, setiap tahapan sudah dilaksanakan namun belum mencapai standar $100 \%$.

\section{Evaluasi model Stake}

Hasil pengamatan diolah secara sistematis melalui evaluasi model Stake (Stake's Countenance Model) untuk mengukur keterlaksanaan proses peran Komite Sekolah yang terjadi di lapangan dengan standar peran Komite Sekolah yang seharusnya sebagai kriteria untuk menentukan keberhasilan. Desain evaluasi model Stake's Countenance Model menekankan adanya pelaksanaan dua hal pokok yakni deskripsi (description) dan pertimbangan keputusan (judgements). Hasil evaluasi melalui model Stake disajikan pada Tabel 2.

Dari bagan proses deskripsi data model Stake ini, dapat dianalisis secara vertikal/atas bawah antara tahap antecedent, transaction, dan outcomes. Pada kondisi yang diharapkan, ketiga tahap memiliki persentase $100 \%$ artinya tidak ada kesenjangan antara ketiga tahap. Namun dalam kondisi sebenarnya, terdapat kesenjangan persentase antara ketiga tahap.

Terdapat kesenjangan antara antecedent dan transaction). Antecedent sebesar 36\% dan transaction sebesar 58\%. Dari kedua tahapan tersebut, ada kenaikan sebesar 22\%. Walaupun pada tahapan antecedent terdapat kekurangan pada aspek-aspeknya, namun yang terjadi pada tahapan transaction ada peningkatan. Berarti proses yang terjadi selama pelaksanaan program komite sekolah lebih baik. Proses pelaksanaan peran komite meliputi peran pendukung, pengontrol, pengembangan, dan mediator. Masingmasing aspek dan pelaksana di lapangan bisa saling bersinergi untuk pelaksanaan program yang baik.

Kesenjangan juga terjadi antara transaction dan outcomes. Transaction dengan persentase
$58 \%$ sedangkan outcomes dengan persentase $47 \%$. Kesenjangan pada kedua tahap tersebut ada penurunan sebesar $11 \%$. Kegiatan evaluasi keterlaksanaan program komite sekolah belum dilakukan secara menyeluruh dan menjadi keterbatasan penelitian.

\section{PEMBAHASAN \\ Tahap Perencanaan}

Pada tahap input dan perencanaan ( $\mathrm{An}$ tecedent Phase) diketahui bahwa pemahaman terhadap rancangan implementasi peran komite sekolah belum sepenuhnya sesuai dengan standar. Rancangan program yang dimaksud dalam hal ini yaitu: konsep, fungsi dan tujuan, serta manfaat komite sekolah. Padahal pemahaman awal tersebut tidak lain merupakan pintu masuk yang merujuk pada bagaimana kontribusi pemangku kepentingan (guru, kepala sekolah, anggota komite sekolah, dan masyarakat) dalam menyusun dan merencanakan program. Hubungan yang positif antar komponen tersebut juga diharapkan dapat dipupuk agar perencanaan terkait misi kerja komite sekolah tersebut dapat dibangun secara optimal. Hal ini membuktikan pendapat dari The Frontier School Board (2014) bahhwa komite sekolah merupakan salah satupemegang peran esensial yang mendukung berkembangnya tata kelola sekolah, sehingga penting bagi mereka untuk memahami aturan-aturan yang ada serta peran mereka sehingga dapat secara positif bekerjasama menjadi bagian dari kemajuan siswa.

Beberapa pertimbangan solutif yang dapat meningkatkan pemahaman setiap anggota komite sekolah terhadap pentingnya membangun rancangan program serta hubungan kerja yang positif adalah dengan sering mengadakan pertemuan/koordinasi antar semua pihak baik guru, kepala sekolah, komite sekolah, wali siswa, dan masyarakat. Pertemuan dilakukan untuk menyamakan pandangan tentang konsep, peran, fungsi dan manfaat komite sekolah.. Selain itu perlu adanya koordinasi antar stakeholder komite sekolah dengan pihak sekolah untuk merencanakan program bersama. Tertulis dalam (SK Mendiknas RI No. 044/U/2002 tentang Dewan Pendidikan dan Komite Sekolah bahwa tata hubungan antara Komite Sekolah dengan satuan pendidikan, Dewan Pendidikan, dan institusi lain yang bertanggungjawab dalam pengelolaan pendidikan dengan Komite Sekolah pada satuan pendidikan lain bersifat koordinatif). Sebaiknya pihak seko- 
lah dengan komite juga melibatkan pemangku kebijakan lainnya seperti pengawas sekolah dan dinas pendidikan dalam upaya untuk memperbaiki kinerja komite sekolah tersebut.

\section{Tahap Proses}

Pada tahapan proses salah satu peran komite sekolah yaitu sebagai pemberi pertimbangan, pendukung, pengontrol dan mediator dalam upaya peningkatan mutu pembelajaran. Ketiganya sudah termasuk dalam kategori baik, namun keterlaksanaannya belum optimal.

Di dalam kedudukannya sebagai pemberi pertimbangan, komite sekolah berkategori baik, namun belum terdapat wadah bagi komite sekolah yang memiliki ruang gerak demokratis untuk saling memberikan sumbang saran yang membangun. Berbeda dengan penelitian yang telah dilakukan Fandhi Yusuf (2015: 103) di SD Unggulan Aisyiyah Bantul, yang menunjukan bahwa komite sekolah dan wali murid memiliki wadah untuk bisa memberikan dukungan, pertimbangan, maupun kontrol terhadap sekolah melalui forum dewan kelas secara mendalam. Dewan kelas merupakan forum pertemuan/silaturahim yang terdiri dari guru, kepala sekolah, wali kelas, dan komite sekolah. Dewan kelas melakukan pertemuan rutin setiap dua bulan sekali. Komite sekolah juga diberi wadah untuk menyalurkan aspirasi terkait pemberian pertimbangan dalam forum rapat RKAS (Rencana Kegiatan dan Anggaran Sekolah) dan uji kurikulum saat awal tahun ajaran baru.

Ruang gerak pertemuan komite sekolah dalam hal ini sangat penting untuk memberikan pertimbangan yang bermanfaat, seperti halnya pernyataan yang telah diungkapkan oleh School Advisory Councils Policy (2007:1) bahwa pendidikan merupakan hasil responbilitas bersama antara orang tua dan anggota masyarakat serta pemerintah, sehingga orang tua melalui komite sekolah memegang peranan penting untuk turut membuat dan mengembangkan kebijakan bersama. Demikian juga yang diungkapkan oleh Michaels (2009:4) bahwa komite sekolah harus mampu menjadi dewan pertimbangan dan penasihat untuk menawarkan keahliannya dalam memperkuat proses pengambilan keputusan/ kebijakan di sekolah.

Aspek peran Komite Sekolah menjadi pendukung juga dalam kategori baik sehingga perlu ditingkatkan, sebab peningkatan kualitas serta berkembangnya suatu sekolah tidak pernah terlepas dari dukungan yang optimal oleh Komite Sekolah, dalam hal ini peneliti memberikan saran/ masukan agar komite turut menaruh perhatian terhadap sekolah terkait dengan perencanaan dan pelaksanaan program-program sekolah. Kemajuan sekolah tersebut akan terwujud apabila komite sekolah mendukung dan menguatkan program-program bermutu yang akan dilaksanakan oleh sekolah. Hal yang juga diungkapkan oleh Ninik, (2011:1) bahwa di SMA I Tuntang Semarang pelibatan komite sekolah ditunjukan dalam pengambilan keputusan, penyusunan rencana dan program sekolah, RAPBS, pelaksanaan program pendidikan dan penyelenggaraan akuntabilitas pendidikan. Pengambilan keputusan berkaitan dengan peran komite sebagai pendukung juga dapat diwujudkan dalam hal anggaran sekolah. Hal ini membuktikan pendapat dari Zajda (2009: 5) dalam Mulyono \& Pardjono (2014: 399) bahwa komite sekolah sangat dominan dalam pengambilan keputusan perencanaan sekolah khususnya dalam pengambilan keputusan tentang anggaran sekolah.

Selanjutnya yaitu terkait dengan peran Komite Sekolah sebagai pengontrol. Merefleksi hasil penelitian, bahwa peran komite sekolah dalam kategori baik namun belum optimal, sehingga perlu ditingkatkan termasuk kedudukannya sebagai pengontrol. Hal tersebut bisa disiasati dengan adanya koordinasi yang baik antara komite sekolah dengan pihak sekolah dalam hal ini kepala sekolah yang memiliki kontrol penuh terhadap sekolah. Kepala sekolah juga selalu memiliki agenda untuk melakukan supervisi terhadap pelaksanaan kegiatan pembelajaran di kelas. Komite dapat melakukan kontrol terhadap proses pembelajaran di sekolah dari hasil pengamatan dan laporan kepala sekolah.

Dalam hal ini, komite dapat memberikan saran/masukan/kritik terkait peran sebagai pengontrol. Keberadaan komite sekolah sebagai langkah untuk menindaklanjuti adanya saran/ $\mathrm{kritik} / \mathrm{keluhan}$ terhadap suatu satuan pendidikan sesuai dengan PP No 17 tahun 2010 pasal 196 ayat (3) yang mengatakan bahawa "Komite sekolah/ madrasah memperhatikan dan menindaklanjuti terhadap keluhan, saran, kritik, dan aspirasi masyarakat terhadap satuan pendidikan. Pertimbangan lain yang bisa dilakukan untuk melakukan kontrol terhadap proses pembelajaran di sekolah adalah dengan memberikan/memasang fasilitas 
CCTV yang rekamannya bisa dilihat langsung oleh komite sekolah setiap saat. Hal ini telah dilakukan di SD Unggulan Aisyiyah Bantul sesuai penelitian dari Fandhi Yusuf (2015: 104). Dengan adanya CCTV, maka kontrol bisa dilakukan oleh komite sekolah melalui pihak sekolah dalam hal ini kepala sekolah yang memiliki wewenang langsung terhadap kegiatan pembelajaran di sekolah.

Terkait kedudukannya sebagai pengontrol, Hanafi (2015) telah melaksanakan penelitian pada SMK di Jakarta bahwa pengawasan terhadap komponen input juga menunjukkan komitmen yang tidak terlalu tinggi, bahkan untuk beberapa komponen input tidak cukup banyak komite sekolah yang melakukannya yaitu hanya $40 \%$. Padahal peran komite sekolah sebagai badan pengawas sangat esensial. Alasan kurangnya pengawasan dari orang tua telah dijelaskan oleh Duma dkk (2011) bahwa orang tua yang tergabung dalam komite sekolah memang sudah seharusnya memastikan bahwa siswa benar-benar bersekolah dan belajar di sekolah. Namun dari hasil penelitian, komite sekolah belum dapat mengontrol proses pembelajaran di sekolah dengan baik dikarenakan keberadaan komite sekolah tidak selalu berada di kelas/di sekolah setiap saat. Hal tersebut sesuai dengan temuan dari Kriswantoro \& Muhyadi (2013:66) bahwa Komite sekolah belum sepenuhnya melaksanakan tugas sebagai pengontrol karena komite sekolah sebagai organisasi yang bersifat sosial dan masing-masing anggota komite mempunyai kesibukan dalam profesi masingmasing sehingga belum mampu melaksanakan kontrol secara langsung di sekolah. Oleh karena itu, pelaksanaan supervisi rutin, kesediaan wadah untuk mengungkapkan kritik dan saran, serta fasilitas CCTV merupakan solusi yang tepat.

Selaku mediator dalam upaya peningkatan mutu pembelajaran, komite sekolah berperan sebagai penghubung antara komponen sekolah dengan masyarakat, komite sekolah dengan sekolah, dan komite sekolah dengan dewan pendidikan. Namun pada kenyataannya pelaksanaannya masih berjalan separuhnya yaitu 52\% sehingga sangat perlu untuk ditingkatkan, diantaranya melalui beberapa solusi yaitu melakukan mediasi dengan pihakpihak di luar sekolah, mendorong siswa memiliki prestasi akademik dan nonakademik yang lebih baik dari sebelumnya, menjadi jembatan penghubung antara sekolah dengan masyarakat. Di dalam hal ini komite sekola sebaiknya turut mengidentifikasi aspirasi dari masyarakat dalam rangkat perencanaan pendidikan.

Selain itu, komite sekolah juga dapat dikatakan sebagai organisasi yang mensosialisasikan kebijakan dan program sekolah kepada masyarakat serta mengkomunikasikan pengaduan keluhan masyarakat terhadap program sekolah. Seperti yang telah dijelaskan oleh Epstein \& Van Voorhis (2010) bahwa komite sekolah berperan dalam mempromosikan kegiatan-kegiatan di sekolah, meningkatkan kinerja akademik, serta menjadi penghubung kemitraan antara sekolah, keluarga, dan masyarakat. Di dalam posisi ini, komite memegang peraan penting untuk menjadi jembatan penghubung antara kebutuhan sekolah dengan masyarakat serta timbal balik diantara keduanya. Peran komite termanifestasi dalam suatu keinginan untuk mengembangkan kualitas pendidikan suatu sekolah yang berlandaskan kebutuhan bersama.

Tahap yang ketiga terkait dengan hasil atau outcomes yang berorientasi pada evaluasi keterlaksanaan. Hasil penelitian menunjukan hasil yang kurang optimal dalam pelaksanannya, yaitu hanya $47 \%$ artinya evaluasi yang dilakukan komite sekolah terhadap keterlaksanaan programprogram sekolah belum maksimal. Oleh karena itu, komite sekolah perlu menyusun rancangan kegiatan selama satu tahun pada awal tahun ajaran baru sehingga langkah-langkah kerja dapat dipetakan dan dapat dievaluasi dengan efektif. Adanya rancangan kegiatan ini, akan menjadi pedoman dalam melangkah. Selanjutnya juga perlu adanya evaluasi kinerja yang dilakukan dalam sebuah rapat/pertemuan komite sekolah dengan melibatkan semua unsur di sekolah untuk mengetahui keterlaksanaan program kerja komite yang telah dirancang di awal tahun ajaran baru.

Seperti penelitian yang dilakukan oleh Santoso (2007: 12) di sekolah dasar di Madiun, bahwa peran komite sekolah dalam rangka meningkatkan mutu pelayanan pendidikan di sekolah adalah dengan melakukan kerja sama dengan pihak sekolah. Bentuk kerja sama yang dilakukan komite sekolah antara lain adalah dengan memberikan dukungan kepada sekolah dalam penyusunan program dan sekaligus realisasinya.

Hal ini membuktikan pendapat dari Matete (2016) bahwa komite sekolah sudah seharusnya memegang peran ikut berkontribusi menyusun rencana pengembangan sekolah baik jangka pendek maupun jangka panjang. Selain itu, komite 
sekolah selalu mendorong guru untuk meningkatkan kinerjanya dalam hal akademis.

\section{SIMPULAN}

Tahap antecedent (input dan perencanaan) terkait dengan pemahaman terhadap rancangan program implementasi peran Komite Sekolah belum sepenuhnya sesuai standar dan berkategori cukup dengan persentase 36\%. Tahap transaction (proses implementasi peran program komite sekolah) terkait dengan implementasi program komite sekolah telah terlaksana dengan kategori baik dengan persentase $58 \%$. Tahap outcomes (evaluasi keterlaksanaan program) terkait dengan evaluasi implementasi peran Komite Sekolah terhadap tahap antecedent dan transaction masuk kategori cukup dengan persentase $47 \%$.

\section{Saran}

Hasil penelitian terhadap evaluasi implementasi peran program komite sekolah di SD Kabupaten Bantul belum semua aspek memenuhi standar $100 \%$. Oleh karena itu, hasil temuan dari penelitian ini diharapkan bisa dijadikan bahan untuk meningkatkan kinerja dari semua pihak. Pihak sekolah dapat memanfaatkan hasil penelitian untuk meningkatkan peran komite sekolah terhadap pelaksanaan pendidikan di sekolah. Dengan melakukan koordinasi antar semua pihak maka pelaksanaan peran program komite sekolah akan lebih optimal. Komite sekolah dapat meningkatkan peran dukungan, pengembangan, kontrol, dan mediasi dengan memanfaatkan temuan penelitian ini.

1. Peningkatan koordinasi antar semua pihak baik guru, kepala sekolah, komite sekolah, wali siswa, dan masyarakat dalam menyamakan pandangan tentang konsep, peran, fungsi dan manfaat komite sekolah.

2. Sekolah bisa juga melakukan kajian terhadap kinerja komite sekolah di sekolah yang lain yang telah berhasil melaksanakan program kerja komite sekolah dengan baik.

3. Pengurus Komite Sekolah lebih meluangkan waktu untuk melaksanakan peran dan fungsinya di sekolah.

4. Keanggotaan komite sekolah dapat melibatkan masyarakat yang berasal dari berbagai latar belakang pendidikan serta bermacam profesi.

5. Komite sekolah hendaknya menyusun rancangan kegiatan selama satu tahun pada awal tahun ajaran baru sehingga langkah kerja bisa dipetakan.
6. Hendaknya diadakan evaluasi kinerja komite sekolah dengan melibatkan semua unsur di sekolah untuk mengetahui keterlaksanaan program kerja komite yang telah dirancang di awal tahun ajaran baru.

\section{UCAPAN TERIMA KASIH}

Dengan diterbitkannya jurnal penelitian ini, ucapan terimakasih disampaikan kepada Komite Sekolah SD, Kepala Sekolah SD, dan beberapa guru SD di Bantul yang telah bekerja sama dalam penelitian ini, dan juga terima kasih kepada Dekan FIP UNY yang telah memberikan dukungan pendanaan untuk pelaksanaan penelitian ini. Semoga amal baik Bapak dan Ibu mendapat balasan berlipat ganda dari Alloh SWT, serta terimakasih disampaikan kepada dewan redaksi Jurnal Cakrawala Pendidikan yang telah memberikan saran perbaikan, proses review, dan kesempatan besar kepada penulis untuk menerbitkan artikel ini.

\section{DAFTAR PUSTAKA}

Bryan, J., \& Henry, L. 2012. A model for building school-family-community partnerships: Principles and process. Journal of Counseling \& Development, 90(4), 408-420.

Departemen Pendidikan Nasional. 2003. UndangUndang Republik Indonesia Nomor 23 Tahun 2003 Tentang Sistem Pendidikan Nasional. Jakarta: Departemen Pendidikan Nasional.

Duma, Kapueja, Khanyile. 2011. Educators' Experiences on the Role of Parents in the School Governing Bodies of Rural Schools. American International Journal of Contemporary Research. Vol. 1 No. 3.

Epstein, J. 1995. School/family/community partnerships: Caring for the children we share. Phi Delta Kappan, 72(5), 701-712.

Hanafi, Ivan \& Mufti Ma'sum. 2015. Analisis Kebijakan Pendidikan: Peran Komite Sekolah pada Sekolah Menengah Kejuruan. Cakrawala Pendidikan, Februari 2015, Th. XXXIV, No. 1.

Jones, Keith. 2004. Planning for Mathematics Learning. Routledge. 
Kavaliauskienë,Galina. 2011. Life Long Learning Strategies. Socialiniu Mokslu Studijjos Societal Studie. Vol. 3(4), p. 1253-1267.

Kemendikbud. 2016. Kemitraan Sekolah dengan Keluarga dan Masyarakat. Jakarta: Direktorat Jendral pendidikan Anak Usia Dini dan Pendidikan Masyarakat.

Kriswantono, M., \& Muhyadi, M. 2013. Implementasi Peran Komite Sekolah di SD Negeri Sumberporong 03 Kecamatan Lawang, Kabupaten Malang. Jurnal Akuntabilitas Manajemen Pendidikan, 1(1). Retrieved fromhttp://journal.uny.ac.id/index.php/ jamp/article/view/2325/1928.

Matete, R. 2016. Teaching Professionalism in an Accountability Age in Tanzania. International Journal of Science and Technology Vol.5 No. 2.

Michaels. 2009. Handbook for Archodiocesan Catolic School Advisooy Boards.

Mulyasa. 2006. Menjadi Kepala Sekolah Profesional. Bandung: Remaja Rosdakarya.

.2007. Medologi Penelitian Kualitatif. Bandung: Remaja Rosda Karya.

. 2009. Manajemen Berbasis Sekolah. Bandung: Remaja Rosdakarya.

Mulyono, W., \& Pardjono, P. 2014. Peran Komite Sekolah Dalam Penyelenggaraan Pendidi- kan SMK Di Kabupaten Lamongan, Jawa Timur. Jurnal Pendidikan Vokasi, 4(3). Retrieved from http://journal.uny.ac.id/index. php/jpv/article/view/2562/2116.

Peraturan Pemerintah Republik Indonesia Nomor 17 tahun 2010 tentang Pengelolaan dan Penyelenggaraan Pendidikan. Jakarta: Departemen Pendidikan Nasional.

Qualifications and Curriculum Authority. 2001. Planning for learning in the foundation stage. London: QCA.

Rehberg, Megan. 2008. School Committee of the Town of Burlington v. Department of Education. SAGE Publications, Inc.

Sagala, Syaiful. 2009. Kemampuan profesional guru dan tenaga kependidikan. Bandung: Alfabeta.

Santoso, Agus Budi. 2007. Peranana Komite Sekolah dalam Meningkatkan Mutu Pendidikan Dasar di Kota Madiun. Skripsi tidak diterbitkan FBS IKIP PGRI Madiun.

Sugiyono. 2007. Metode Penelitian Kuantitatif dan Kualititatif dan $R \& D$. Bandung: Alfabeta.

2012. Metode Penelitian Pendidikan Pendekatan Kuantitatif, Kualitatif, dan $R \& D$. Bandung: Alfabeta. 